\title{
Downregulation of Incrna uca1 as a diagnostic and prognostic biomarker for ovarian endometriosis
}

\author{
(iD) Huan Huang ${ }^{1}$ \\ (iD) Zhenayan Zhu' \\ (iD Yu Song ${ }^{1}$
}

1. Department of Gynecology, Tongren Hospital of Wuhan University (Wuhan Third Hospital), Wuhan City, Hubei Province, 430074, China

\begin{abstract}
SUMMARY
OBJECTIVE: Ovarian endometriosis seriously affects the quality of life of females, and long non-coding RNA IncRNA urothelial carcinoma-associated 1 (UCA1) plays pivotal roles in the pathogenesis of various ovarian diseases. However, the involvement of IncRNA UCA1 in ovarian endometriosis remains unknown to date. Therefore, the present study aims to study the role of UCA1 in ovarian endometriosis.

METHODS: A total of 98 patients with ovarian endometriosis and 28 healthy females were included. The expression of IncRNA UCA1 in ectopic and eutopic endometrium tissues of ovarian endometriosis patients and controls was detected using qRT-PCR. A ROC curve analysis was performed to evaluate the diagnostic values of serum IncRNA UCA1 for ovarian endometriosis. Patients were followed up for 2 years after discharge, and the recurrence of ovarian endometriosis was recorded.

RESULTS: The expression level of InCRNA UCA1 was significantly higher in ectopic endometrium tissues than in paired eutopic endometrium tissues for most of the patients. The serum InCRNA UCA1 level showed no significant correlations with either patients' age or living habits. After the treatment, the serum InCRNA UCA1 level increased, and serum levels of IncRNA UCA1 on the day of discharge were significantly lower in patients with recurrence than those in patients without recurrence. Conclusion: The downregulation of InCRNA UCA1 is involved in the pathogenesis of ovarian endometriosis and may serve as a promising diagnostic and prognostic biomarker for the disease.
\end{abstract}

KEYWORDS: Endometriosis. RNA, Long Noncoding. Biomarkers. Endometrium/pathology.

\section{INTRODUCTION}

Endometriosis is the abnormal growth of endometrial tissue outside the uterine cavity. As a chronic gynecological disease, it can cause chronic pelvic pain and infertility'. Endometriosis may affect different organs and tissues. Based on the sites of endometrial-type mucosa, endometriosis can be divided into different subtypes such as ovarian and peritoneal endometriosis ${ }^{2}$. Ovarian endometriosis is one of the most common types and can reduce or even elimi- nate the fertility potential of females. The incidence of ovarian endometriosis is predicted to be increasing among females worldwide due to the extended ovulatory menstruation period ${ }^{3}$. At present, laparoscopic surgery is the most commonly used treatment for patients with ovarian endometriosis ${ }^{4}$. However, the recurrence rate of ovarian endometriosis within 2 years for patients without proper postoperative treatment can be as high as $40 \%{ }^{5}$. Even for patients 
with appropriate postoperative treatment, the incidence is still around $10 \%{ }^{6}$. Therefore, how to inhibit postoperative recurrence is the primary objective of the treatment for ovarian endometriosis.

Long non-coding RNA IncRNA urothelial carcinoma-associated 1 (UCA1) has been proved to participate in the pathogenesis of various human diseases including different types of ovarian diseases, such as ovarian cancer ${ }^{7}$. A recent microarray study has shown that lncRNA UCA1 expression was inhibited in patients with ovarian endometriosis, ${ }^{8}$ indicating the potential involvement of lncRNA UCA1 in the disease. In this study, the expression of IncRNA UCA1 in ectopic endometrium tissues and paired eutopic endometrium tissues of ovarian endometriosis patients as well as serum from both patients and controls were detected. A ROC curve analysis was performed to evaluate the diagnostic value of serum IncRNA UCA1 for ovarian endometriosis. Patients were followed up for 2 years after discharge, and the recurrence of ovarian endometriosis was recorded. We found that the downregulation of IncRNA UCA1 is very likely to be involved in the pathogenesis of ovarian endometriosis and the serum IncRNA UCA1 may serve as a promising diagnostic and prognostic biomarker for the disease.

\section{METHODS}

\section{Patients}

A total of 98 patients with ovarian endometriosis (diameter between 6 and $7 \mathrm{~cm}$ under laparoscopy) were selected from January 2013 to January 2015 in the Tongren Hospital of the Wuhan University. The age of those patients ranged from 22 to 41 years old. All patients were diagnosed using pathological examinations and received laparoscopic surgeries so that ectopic endometrium tissues and paired eutopic endometrium tissues from the same person were obtained during surgical operations. Patients with abnormal menstrual cycles and treated with hormonal medicine for 3 months before surgery were excluded. The American Fertility Society (AFS) staging was performed per the revised American Society for Reproductive Medicine staging (1997). There were 19 patients in stage I, 21 patients in stage II, 33 patients in stage III and 25 patients in stage IV. No significant differences in age and other basic background information were found among patients in different AFS stages. At the same time, 28 normal healthy females with the same age distribution were also selected to serve as the control group, which was only subjected to blood extraction. The Tongren Hospital of the Wuhan University ethics committee approved this study, and all the patients signed informed consent. All patients were followed up for 2 years through telephone and outpatient service. The recurrence of ovarian endometriosis was diagnosed by pathological examinations.

\section{Preparation of serum samples}

Fasting blood $(20 \mathrm{ml})$ was extracted from each patient one day before the surgery and on the day of discharge. Blood samples were kept at room temperature for 2 hours, followed by centrifugation at $1200 \mathrm{~g}$ for $15 \mathrm{~min}$ to collect serum. The serum was kept at $-80^{\circ} \mathrm{C}$ before use.

\section{Real-time quantitative PCR (qRT-PCR)}

Trizol reagent (Invitrogen, USA) was used to extract total RNA from serum samples, ectopic and paired eutopic endometrium tissues. All RNA samples were tested using NanoDrop ${ }^{\mathrm{TM}} 2000$ Spectrophotometers (Thermo Fisher Scientific, USA), and only the ones that showed a ratio of A260/A280 between 1.8 and 2.0 were used in the reverse transcription for cDNA synthesis using iScript ${ }^{\mathrm{TM}} \mathrm{cDNA}$ Synthesis Kit (Bio-Rad, CA, USA). The PCR reaction system was prepared using SYBR ${ }^{\circledR}$ Green Real-Time PCR Master Mixes (Thermo Fisher Scientific, USA). The PCR reactions were performed on the ABI 7500 System. The primers used in PCR reactions were: 5'-TTTATGCTTGAGCCTTGA-3' (forward) and 5'-CTTGCCTGAAATACTTGC-3' (reverse) for IncRNA UCA1; 5'-GACCTCTATGCCAACACAGT-3' (forward) and 5'-AGTACTTGCGCTCAGGAGGA-3' (reverse) for $\beta$-actin. The PCR reaction conditions were: $95^{\circ} \mathrm{C}$ for $40 \mathrm{~s}$, followed by 40 cycles of $95^{\circ} \mathrm{C}$ for $20 \mathrm{~s}$ and $60^{\circ} \mathrm{C}$ for $45 \mathrm{~s}$. Ct (threshold cycle) values were processed using the 2- $\Delta \Delta \mathrm{CT}$ method. The relative expression level of IncRNA UCA1 was normalized to endogenous control $\beta$-actin.

\section{STATISTICAL ANALYSIS}

SPSS19.0 (SPSS Inc., USA) was used for statistical analysis. Measurement data were recorded by $\left({ }^{\prime} x+s\right)$, and comparisons between two groups were performed using the t-test. While comparisons among 
multiple groups were performed using one-way analysis of variance and LSD test, the correlation between serum levels of IncRNA UCA1 and clinical data of patients was analyzed using the chi-square test. A ROC curve analysis was used to evaluate the diagnostic value of serum IncRNA UCA1 for ovarian endometriosis patients in different AFS stages. $\mathrm{P}<0.05$ was considered to be statistically significant.

\section{RESULTS}

Comparison of expression levels of lncRNA UCA1 in ectopic and paired eutopic endometrium tissues from ovarian endometriosis patients

The expression of IncRNA UCA1 in ectopic and paired eutopic endometrium tissues in patients with ovarian endometriosis was detected by qRT-PCR. As shown in Fig. 1a, the expression level of IncRNA UCA1 was significantly lower in ectopic endometrium tissues than that in paired eutopic endometrium tissues in 89 out of 98 patients with ovarian endometriosis $(\mathrm{p}<0.05)$.
Serum levels of IncRNA UCA1 on healthy controls and patients with different stages of ovarian endometriosis

Serum levels of lncRNA UCA1 (one day before surgery) on healthy controls and patients with different stages of ovarian endometriosis were measured using qRT-PCR. As shown in Fig. 1b, compared with healthy controls $(9.8 \pm 3.3)$, serum levels of lncRNA UCA1 were significantly reduced in patients with different stage I ( $7.7 \pm 1.8)$, stage II (4.9 \pm 1.1$)$, stage III (4.1 \pm 0.5$)$ and stage IV $(2.9 \pm 0.3)$ ovarian endometriosis ( $p$ 0.05). Also, serum levels of IncRNA UCA1 were significantly reduced with the increased AFS stages $(p<0.05)$.

Diagnostic values of serum IncRNA UCA1 on patients with different stages of ovarian endometriosis

A ROC curve analysis was performed to evaluate the diagnostic values of serum IncRNA UCA1 on patients with different stages of ovarian endometriosis. As shown in Fig. 2A, the area under the curve (AUC)
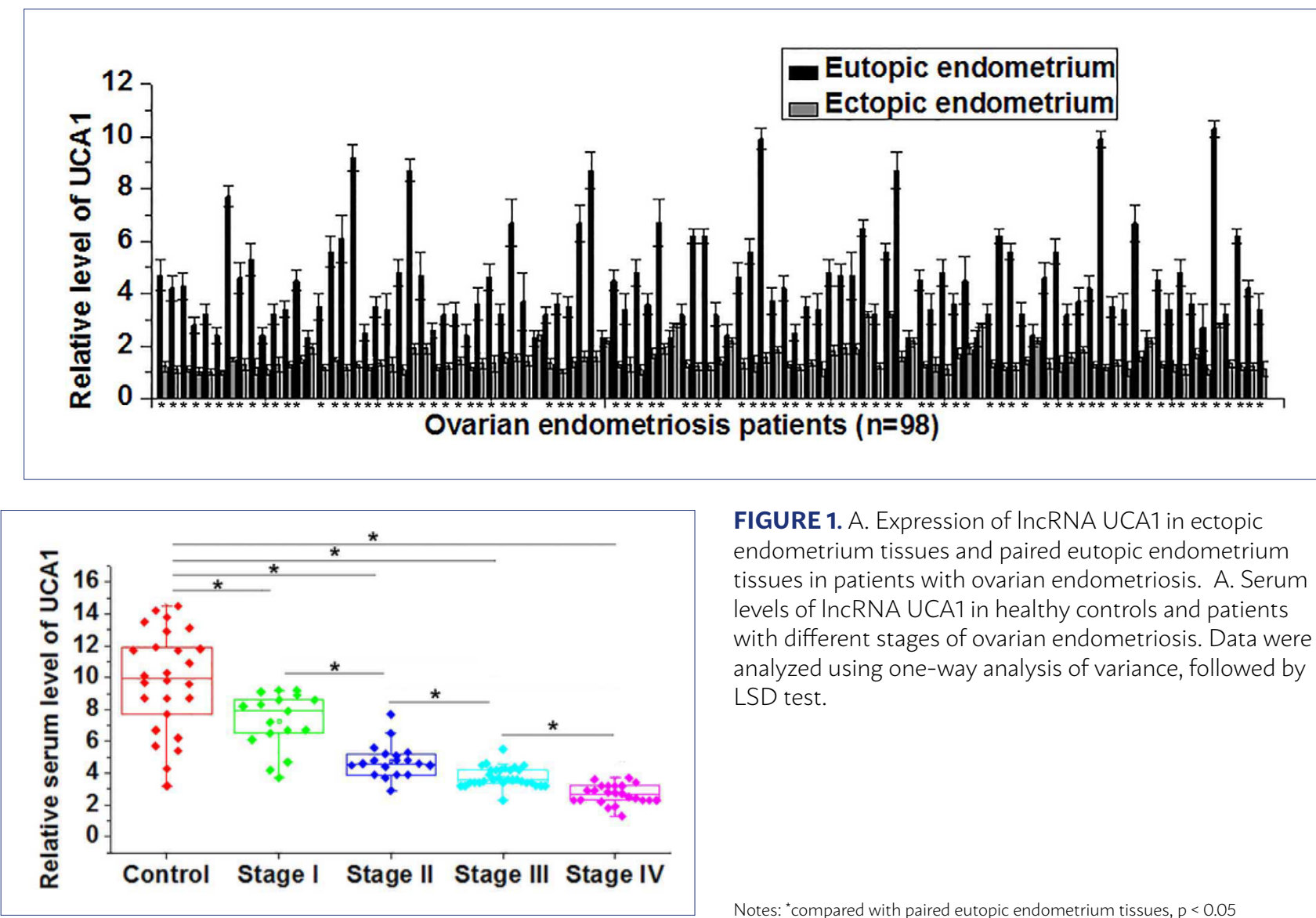

FIGURE 1. A. Expression of IncRNA UCA1 in ectopic endometrium tissues and paired eutopic endometrium tissues in patients with ovarian endometriosis. A. Serum levels of IncRNA UCA1 in healthy controls and patients with different stages of ovarian endometriosis. Data were analyzed using one-way analysis of variance, followed by LSD test. 
of serum lncRNA UCA1 in the diagnosis of ovarian endometriosis patients in Stage I was 0.7509 with 95 \% confident interval of 0.6109 to 0.8910 , specificity of $80.1 \%$ and sensitivity of $76.7 \%(p=0.003820)$. For stage II, AUC was 0.9175 with $95 \%$ confident interval of 0.8308 to 1.004 , specificity of $85.6 \%$ and sensitivity of $81.1 \%$ ( $p<0.0001$; Fig 2 , panel B). For stage III, AUC was 0.9605 with $95 \%$ confident interval of 0.8982 to 1.023 , specificity of $89.1 \%$ and sensitivity of 88.1\% ( $\mathrm{p}<0.0001$; Fig 2. panel C). For stage IV, AUC was 0.9921 with $95 \%$ confident interval of 0.9747 to 1.010 , specificity of $90.5 \%$ and sensitivity of $89.0 \%$ (p $<0.0001$; Fig 2, panel D).

Correlation between serum levels of IncRNA UCA 1 and the clinical data of patients

According to the median serum level of IncRNA UCA1, the 98 patients with ovarian endometriosis were divided into a high expression and a low expression group. The serum level of IncRNA UCA1 was not affected by the patients' age and living habits, including vegetarian, smoking and drinking $(p<0.05)$.
Comparison of serum levels of IncRNA UCA1 before and after treatment and between patients with or without recurrence of ovarian endometriosis

Compared with the pretreatment level of serum IncRNA UCA1, the serum level of IncRNA UCA1 was significantly increased in those patients after treatment ( $<<0.05$; Fig 3 , panel A). A total of 28 cases of ovarian endometriosis recurrence were observed during a two-year follow-up. The serum levels of lncRNA UCA1 (on the day of discharge) were significantly lower in patients with recurrence than in patients without recurrence ( $\mathrm{p}<0.05$; Fig 3 , panel B).

\section{DISCUSSION}

The abnormal expression of IncRNA UCA1 has been observed in the development of various types of human diseases. In the study of lung cancer, Wang et al. ${ }^{9}$ found that IncRNA UCA1 expression in plasma was more significantly upregulated in lung cancer patients than in healthy controls, and the increased
A

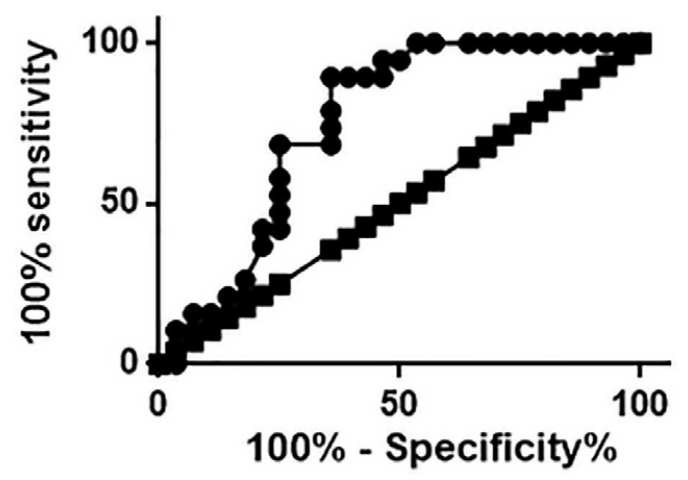

C

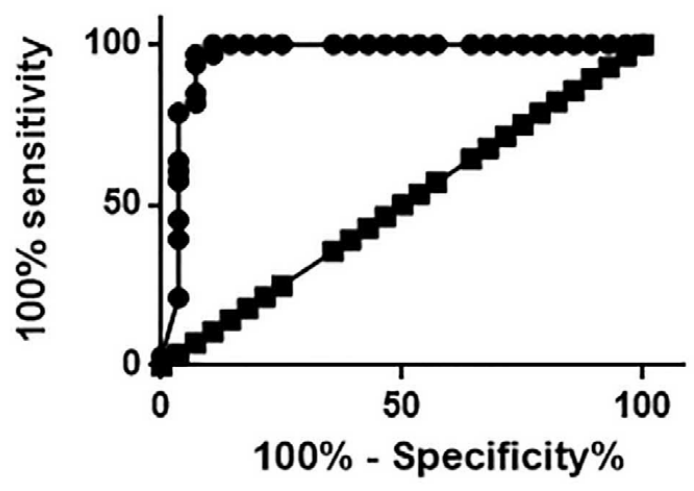

B

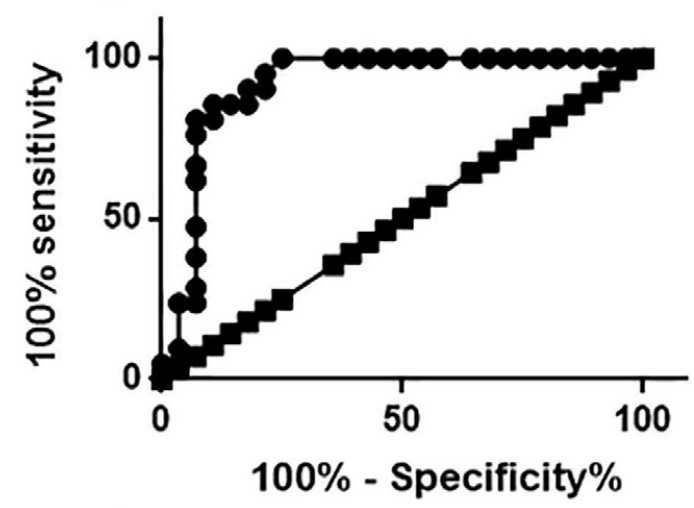

D

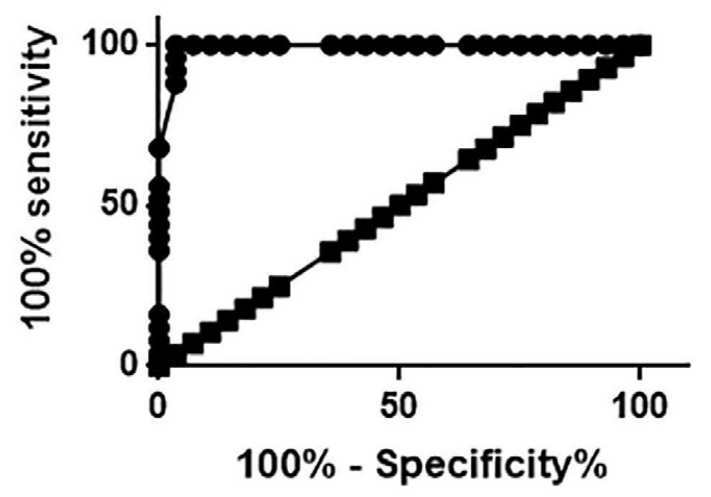

FIGURE 2. Diagnostic value of serum IncRNA UCA1 for patients with different stages of ovarian endometriosis. A-D indicate diagnostic values of serum IncRNA UCA1 for ovarian endometriosis patients in stage I, II, III and IV, respectively. 
expression level of IncRNA UCA1 contributed to the progression of the disease. Upregulation of IncRNA UCA1 was also observed in breast cancer and was proved to be correlated with an accelerated epithelial-mesenchymal transition of the breast tumor. In contrast, the occurrence of acute myocardial infarction was accompanied by the reduced level of circulating IncRNA UCA1. LncRNA UCA1 showed different expression patterns in different ovarian diseases. LncRNA UCA1 overexpression not only related to the progression of ovarian cancer but was also responsible for poor treatment outcomes after adjuvant chemotherapy. However, lncRNA UCA1 expression was downregulated in patients with ovarian endometriosis $^{8}$. Consistent with previous studies, in this study, the expression level of IncRNA UCA1 was found to be significantly lower in ectopic endometrium tissues than in paired eutopic endometrium tissues in 89 out of 98 patients with ovarian endometriosis. Also, serum levels of IncRNA UCA1 were significantly reduced in patients with different stages of ovarian endometriosis in comparison with healthy controls, and serum levels of IncRNA UCA1 were significantly reduced with increased AFS stages. These data suggest that the downregulation of IncRNA UCA1 is involved in the development and progression of ovarian endometriosis.

In this study, a ROC curve analysis was performed to evaluate the diagnostic values of serum lncRNA UCA1 on patients with different stages of ovarian endometriosis. We found that serum IncRNA UCA1 level could be referred to diagnose ovarian endometriosis patients accurately. Especially for those in AFS stage IV, AUC reached 0.9921 with $95 \%$ confident interval of 0.9747 to 1.010 . Therefore, serum lncRNA UCA1 may serve as a promising diagnostic marker for ovarian endometriosis. The expression of certain lncRNAs is significantly affected by an individual's age and living habits such as smoking, alcohol consumption, and diet. In this study, no significant correlations were found between serum levels of lncRNA UCA1 and patients' age and living habits including drinking, smoking, and vegetarianism. Therefore, these variables may be ignored in the diagnosis of ovarian endometriosis using lncRNA UCA1.

After the treatment, serum levels of IncRNA UCA1 were significantly increased compared with the pretreatment levels. At present, the treatment for ovarian endometriosis using laparoscopic surgery is still challenged by the high postoperative recurrence rate. The recurrence rate of ovarian endometriosis within 2 years after laparoscopic surgery for patients without proper postoperative treatment reaches $40 \%{ }^{5}$, and for patients with appropriate postoperative treatment, the incidence is still as high as $10 \%{ }^{6}$. In the current study, all patients were followed up for two years after discharge, and none of them was missed. During follow-up, a total of 28 cases of recurrence were observed, which accounted for $28.6 \%$ of the total. A comparison of serum levels of IncRNA UCA1 on the day of discharge showed that the serum levels of IncRNA UCA1 were significantly lower in patients with recurrence than in patients without recurrence. These results suggest that lncRNA UCA1 may serve

FIGURE 3. Comparison of serum levels of IncRNA UCA1 regarding treatment and recurrence of ovarian endometriosis A. Comparison of serum levels of IncRNA UCA1 before and after treatment; B. Comparison of serum levels of IncRNA UCA1 between patients with and without recurrence of ovarian endometriosis.
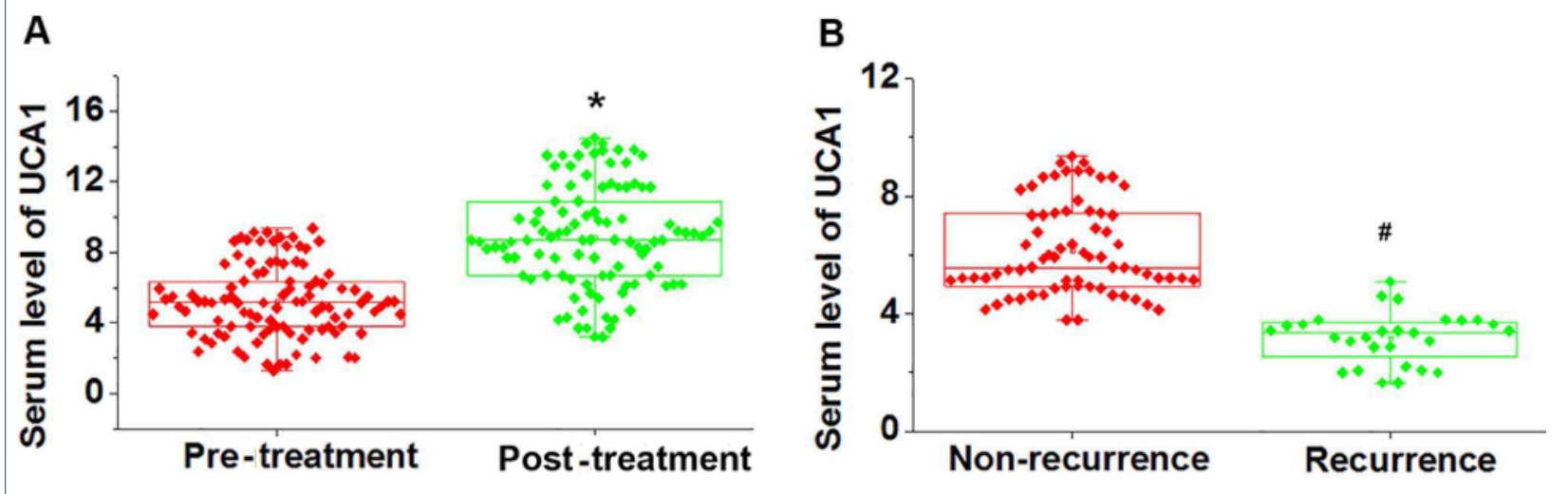

Notes: ${ }^{*}$ compared with pretreatment level, $p<0.05$; \#compared with patients with recurrence, $p<0.05$ 
as a target for the treatment of ovarian endometriosis, and low serum levels of IncRNA UCA1 after laparoscopic surgery may predict recurrence of the disease. A recent study revealed that different types of endometriosis might have a different gene expression pattern. Our future study will focus on identifying the functionality of IncRNA UCA1 in different types of endometriosis, such as superficial and deep infiltrating endometriosis ${ }^{10}$.

\section{CONCLUSION}

The expression level of IncRNA UCA1 was significantly higher in ectopic endometrium tissues than that in paired eutopic endometrium tissues in most patients. Compared with healthy controls, serum levels of IncRNA UCA1 were decreased in patients with ovarian endometriosis, and serum levels of UCA1 were further decreased with the progression of this disease. The serum IncRNA UCA1 level showed no significant correlations with either patients' age or living habits. After the treatment, the serum IncRNA UCA1 level was increased, and the serum levels of lncRNA UCA1 on the day of discharge were significantly lower in patients with recurrence than in those without recurrence. Based on these data, we can conclude that the downregulation of IncRNA UCA1 is involved in the pathogenesis of ovarian endometriosis and might be a promising diagnostic and prognostic biomarker for the disease. Our study is limited by the small sample size due to the limited resources of patients and healthy volunteers. Future studies with more significant sample size are needed to confirm these conclusions further.

\section{RESUMO}

OBJETIVO: A endometriose ovariana afeta seriamente a qualidade de vida das mulheres, e o carcinoma urotelial 1 de urcélio de RNA não codificador longo 1 (UCA1) desempenha um papel crucial na patogênese de várias doenças ovarianas. No entanto, o envolvimento do IncRNA UCA1 na endometriose ovariana permanece desconhecido até o momento. Portanto, o presente estudo tem como objetivo estudar o papel do UCA7 na endometriose ovariana. Métodos: Um total de 98 pacientes com endometriose ovariana e de 28 mulheres saudáveis foi incluído. A expressão de InCRNA UCA1 em tecidos de endométrio ectópico e eutópico de pacientes com endometriose ovariana e controles foi detectada por qRT-PCR. A análise da curva ROC foi realizada para avaliar os valores diagnósticos do IncRNA UCA1 sérico para endometriose ovariana. Os pacientes foram acompanhados por dois anos após a alta, e a recorrência da endometriose ovariana foi registrada.

RESULTADOS: O nível de expressão do InCRNA O UCA1 foi significativamente maior nos tecidos do endométrio ectópico do que nos tecidos do endométrio eutópico pareados para a maioria dos pacientes. O nível sérico de UCA1 foi diminuído com a progressão da endometriose ovariana. O soro UCA1 pode ser usado para diagnosticar com precisão a endometriose ovariana. O nível sérico de UCA1 não apresentou correlações significativas com a idade ou com os hábitos de vida dos pacientes. Após o tratamento, o nível sérico do IncRNA UCA1 foi aumentado, e os níveis séricos de IncRNA UCA1 no dia da alta foram significativamente menores nos pacientes com recidiva do que naqueles sem recorrência.

CONCLUSÃO: A regulação negativa do InCRNA UCA1 está envolvida na patogênese da endometriose ovariana e pode servir como um promissor biomarcador diagnóstico e prognóstico para a doença.

PALAVRAS-CHAVE: Endometriose. RNA longo não codificante. Biomarcadores. Endométrio/patologia.

\section{REFERENCES}

1. Vercellini P, Viganò P, Somigliana E, Fedele L. Endometriosis: pathogenesis and treatment. Nat Rev Endocrinol. 2014;10(5):261-75.

2. Nisolle M, Donnez J. Peritoneal endometriosis, ovarian endometriosis, and adenomyotic nodules of the rectovaginal septum are three different entities. Fertil Steril. 1997;68(4):585-96.

3. Bulun SE. Ovarian endometriosis: the nemesis of eggs. Fertil Steril. 2014;101(4):938-9.

4. Duffy |M, Arambage K, Correa F), Olive D, Farquhar C, Garry R, et al. Laparoscopic surgery for endometriosis. Cochrane Database Syst Rev. 2014;(4):CD011031.

5. Cucinella G, Granese R, Calagna G, Svelato A, Saitta S, Tonni G, et al. Oral contraceptives in the prevention of endometrioma recurrence: does the different progestins used make a difference? Arch Gynecol Obstet. 2013;288(4):821-7.

6. Somigliana E, Vercellini P, Vigano P, Benaglia L, Busnelli A, Fedele L.
Postoperative medical therapy after surgical treatment of endometriosis: from adjuvant therapy to tertiary prevention. J Minim Invasive Gynecol. 2014;21(3):328-34.

7. Yang $Y$, Jiang $Y$, Wan $Y$, Zhang L, Qiu J, Zhou S. UCA1 functions as a competing endogenous RNA to suppress epithelial ovarian cancer metastasis. Tumor Biol. 2016;37(8):10633-41.

8. Sun PR, Jia SZ, Lin H, Leng JH, Lang JH. Genome-wide profiling of long noncoding ribonucleic acid expression patterns in ovarian endometriosis by microarray. Fertil Steril. 2014;101(4):1038-46.

9. Wang HM, Lu JH, Chen WY, Gu AQ. Upregulated IncRNA-UCA1 contributes to progression of lung cancer and is closely related to clinical diagnosis as a predictive biomarker in plasma. Int J Clin Exp Med. 2015;8(7):11824-30.

10. Fettback PB, Pereira RM, Rocha AM, Soares JM Jr, Smith GD, Baracat EC, et al. Expression of stem cell-related genes in the endometrium and endometriotic lesions: a pilot study. Gynecol Endocrinol. 2016;32(1):82-6. 